Jurnal Kebidanan Mutiara Mahakam, Vol 7 , No 2, 2019, Hal 67-73

ISSN : 2623-2553 (Online)

ISSN : 2549-0532 (Cetak)

\title{
PENGARUH PENGGUNAAN ASI PADA PERAWATAN LUKA PERINIEM DENGAN LAMA WAKTU PENYEMBUHAN LUKA PERINIUM
}

\author{
Annisa Ul Mutmainnah ${ }^{1}$, Siti Noorbaya ${ }^{2}$ \\ ${ }^{1}$ Akademi Kebidanan Mutiara Mahakam \\ ${ }^{2}$ Akademi Kebidanan Mutiara Mahakam \\ Email: annisamutmainnah11@gmail.com, sitinoorbayanaz.y@gmail.com \\ $\begin{array}{ll}\text { Dikirim } & : 13 \text { September } 2019 \\ \text { Diterima } & : 20 \text { September } 2019 \\ \text { Dipublikasi } & : 28 \text { September } 2019\end{array}$
}

\begin{abstract}
Childbirth is a natural process, but sometimes labor can also cause birth canal trauma, especially in the aluminum region, this trauma can be injuries to the perinium area, the cause can be intentional biases such as episiotomy or unintentional actions such as spontaneous tears in the process of removing the baby. Injury to the perineum if not treated properly can cause postpartum infection because the wound area will be a medium for developing germs. The purpose of this study was to analyze the effect of the use of breast milk in the treatment of periniem wounds with the duration of perinium wound healing at the Ramlah Parjib Clinic in Samarinda. The method used in this study was Posttest Only Control Group Desigen research subjects were postpartum mothers with a sample of 60 respondents taken by random sampling and grouped based on treatment using ASI. Data analysis using ANOVA test. The results showed that the use of ASI had a significant effect on the treatment of periniem wounds with a healing time seen from the P value of 0,000. Conclusion: Periniuem wound care techniques are factors that influence the duration of perinieum wound healing
\end{abstract}

Keywords: Perinium wounds, breast milk 
Jurnal Kebidanan Mutiara Mahakam, Vol 7 , No 2, 2019, Hal 67-73

\section{PENDAHULUAN}

Angka kematian dan kesakitan ibu yang digunakan sebagai indicator dari kesehatan masyarakat di suatu negara, menurut Survey Demografi dan Kesehatan Indonesia Tahun 2012, angka kematian ibu (AKI) adalah 359 / 100.000 kelahiran hidup, walaupun terjadi penurunan AKI pada tahun 2016 yaitu 305/100.000 kelahiran hidup namun penurunan tersebut tidak signifikan. Tingginya kasus kesakitan dan kematian ibu dibanyak Negara berkembang termasuk Indonesia, disebabkan oleh kasus Eklamsia (23\%), perdarahan pasca persalinan (22\%), komplikasi pasca keguguran (12\%) dan infeksi (9\%). Salah satu penyebab infeksi adalah dikarenakan robekan perinuim. Robekan perineum merupakan robekan yang terjadi pada aera perinium yang diakibatkan oleh proses persalinan. Robekan perineum ini merupakan media yang baik bagi kuman untuk berkembangbiak jika tidak mendapatkan perawatan yang tepat. Hal ini juga merupakan salah satu penyebab bervariasinya lama penyembuhan luka perineum tersebut. Lamanya waktu penyembuhan luka dan tehnik perawatan yang tidak tepat dapat mengakibatkan infeksi postpartum(JNPK_KR,2017). Perawatan luka yang biasa dilakukan dimasyarakat dapat dilakukan dengan mengaplikasikan cairan povidone iodine pada area luka atau salep gentamycin. Pada beberapa literature diketahu bahwa Asi adalah factor pertumbuhan yang sangat baik karena mengandung TGF $\alpha$ dan TGF $\beta$ tidak hanya itu Asi juga mengandung IGF-1 dan IGF-2 dimana komponen-komponen ini berperan aktif dalam proses pertumbuhan dan perkembangan sel-sel baru pada area luka, tidak hanya itu, ASI juga mengandung molekul specialized pro-resolving mediators (SPMs) yang dapat menyembuhkan luka, mengurangi peradangan dan menyembuhkan infeksi. Penelitian yang dilaksanakan di Buston pada tahun 2016 menyebutkan bahwa ASI bisa digunakan untuk perawatan luka perineum karena mengandung molekul anti inflamasi yang disebut dengan specialized pro-resolving mediators (SPMs) sebagai zat bioaktif yang terkandung dalam ASI, Molekul bioaktifnya berguna untuk menyembuhkan luka terutama pemulihan cidera (Admasari, 2017) ASI secara epidemiologis dan klinik mengandung antibody, anti inflamasi dan antioksi dan seperti Vitamin A,B, E, enzimekatalase, dan glutathione peroxide, serta sangat kaya akan sel darah putih yang memiliki kemampuan untuk membunuh kuman secara langsung maupun tidak langsung. (Arnardottir,2016) Pada penelitian ini akan dilakukan observasi pada 3 kelompok, yaitu kelompok 1 dengan ibu pospartum yang luka periniumnya di rawat menggunakan ASI, kelompok 2 di rawat dengan menggunakan Povidone Iodine, dan kelompok 3 yang 
Jurnal Kebidanan Mutiara Mahakam, Vol 7 , No 2, 2019, Hal 67-73

dirawat dengan menggunakan Gentamycin lalu kemudian di observasi lama penyembuhan luka perineum pada masing-masing kelompok.

\section{METODE PENELITIAN}

Penelitian ini dlakukan di Klinik Ramlah Parjib 2 pada bulan April- Juni 2019. Sesuai dengan tujuan penelitian, jenis penelitian ini dikategorikan sebagai penelitian eksperimen. Penelitian eksperimen merupakan kegiatan penelitian untuk mengontrol, memanipulasi dan mengobservasi subjek penelitian. Desain eksperimen yang digunakan pada penelitian ini adalah desain eksperimen sederhana (Posttest Only Control Group Design). Dalam desain eksperimen sederhana terdapat tiga kelompok yang dipilih secara random. Satu kelompok bertindak sebagai kelompok Eksperimen dan ada dua kelompok yang bertindak sebagai kelompok kontrol. Kelompok yang diberikan perlakuan disebut sebagai disebut kelompok eksperimen yang pada penelitian ini akan diberikan intervensi pemberian ASI. Sedangkan yang tidak diberi perlakuan disebut kelompok kontrol, yang pada penelitian ini hanya akan diberikan perawatan luka perinium dengan menggunakan Povidone Iodine dan Gentamycin. setelah selesai diberikan perlakuan, dilakukan pengukuran terhadap kedua kelompok. Variabel Penelitian Variabel bebas dalam penelitian ini adalah tehnik perawatan tali pusat, dan variabel bebas dalam penelitian ini adalah lama penyembuhan luka perinium. Subjek dan Objek Penelitian Subjek dalam penelitian ini adalah ibu nifas dengan luka perinium. Sedangkan objek penelitiannya adalah luka perinium yang di berikan masing-masing tehnik perawatan yang berbeda yaitu kelomok I dengan menggunakan ASI, kelompok II dengan menggunakan Povidone Iodine dan kelompok III dengan menggunakan Gentamycin. Penelitian ini akan membagi kelompok perlakuan menjadi 3 kelompok yaitu : kelompok 1 dengan tehnik perawatan luka perinium dengan menggunakan ASI (Perawatan perineum dilakukan 2 kali sehari menggunakan ASI yang diperah secukupnya lalu kemudian ditempatkan pada tempat yang bersih dan dioleskan menggunakan kapas pada aera luka), kelompok 2 tehnik perawatan luka perineum dengan menggunakan Povidone Iodine (Povidone Iodine 10\% diaplikasikan menggunakan kapas), kelompok 3 tehnik perawatan luka perinium dengan gentamycin (salep gentamycin diaplikasin menggunakan jari ibu yang sudah dibersihkan terlebih dahulu menggunakan sabun). Perawatan perinium pada ketiga kelompok dilakukan oleh peneliti utama, peneliti kedua dan tiga bidan sebagai pembantu peneliti untuk mengunjungi rumah masing-masing responden selama 7 hari. Penilaian penelitian ini menggunakan skala REEDA dilakukan sebanyak 4 kali yaitu ; Periode I (6-10 jam 
Jurnal Kebidanan Mutiara Mahakam, Vol 7 , No 2, 2019, Hal 67-73

postpartum), periode II (20-24 jam postpartum), periode III (25 - 48 jam), periode IV (7 hari postpartum). Skor mulai dari 0 hingga 3 dapat diberikan, nilai maksimum 15 menunjukan hasil penyembuhan perineum yang paling lambat.

Data yang dikumpulkan terdiri atas data sekunder dan data primer. Data primer melalui pengamatan terhadap kondisi luka dan lama penyembuhanya. Sedangkan data sekunder diperoleh dari data rekam medis yang meliputi: Identitas responden dan status responden. Instrumen yang digunakan dalam penelitian ini adalah lembar observasi. Lembar observasi ini digunakan untuk mencatat kemajuan proses penyembuhan luka perinium. Berdasarkan jenis penelitian dan jenis data yang diperoleh, maka analisis yang digunakan dalam penelitian ini adalah analisis kuantitatif dengan menggunakan rumus statistik. Rumus statistik dilakukan karena data-data yang diperoleh berupa angka-angka dan bersifat kuantitaf. Analisis dalam penelitian ini dilakukan menggunakan program SPSS (Statistic Program For Social Sciences)Setelah memberikan perlakuan selama tiga bulan, maka dilakukan post-test pada masing-masing kelompok yang dinilai dari lama waktu penyembuhan luka perinium. Uji normalitas data yang digunakan pada penelitan ini adalah kolmogorov smirnov. Analisis statistik yang digunakan pada penelitian ini adalah One Way Anova.

\section{HASIL DAN PEMBAHASAN}

\section{A. HASIL}

1. Karakteristik Responden

Tabel 1.1

Karakteristik Responden Berdasarkan Usia

\begin{tabular}{llll}
\hline No & Usia & $\sum$ & $\%$ \\
1 & $<20$ Tahun & 2 & 3,4 \\
2 & $20-35$ Tahun & 57 & 95 \\
3 & $>$ 35 Tahun & 1 & 1.6 \\
TOTAL & $\mathbf{6 0}$ & $\mathbf{1 0 0}$ \\
\hline
\end{tabular}

Berdasarkan tabel 1.1 da[at diketahui bahwa mayoritas responden adalah ibu postpartum yang berusia 20-35 tahun yaitu sejumlah 57 responden (95\%).

Tabel 1.2

Karakteristik Responden Berdasarkan Pekerjaan

\begin{tabular}{llll}
\hline No & Pekerjaan & $\sum$ & \% \\
1 & Bekerja & 19 & 32 \\
2 & Tidak Bekerja & 41 & 68 \\
TOTAL & $\mathbf{6 0}$ & $\mathbf{1 0 0}$ \\
\hline
\end{tabular}


Jurnal Kebidanan Mutiara Mahakam, Vol 7 , No 2, 2019, Hal 67-73

Berdasarkan tabel 1.2 dapat diketahui bahwa mayoritas responden adalah ibu postpartum yang tidak bekerja yaitu sejumlah 41 responsen $(68 \%)$

Tabel 1.3

Karakteristik Responden Berdasarkan Pendidikan

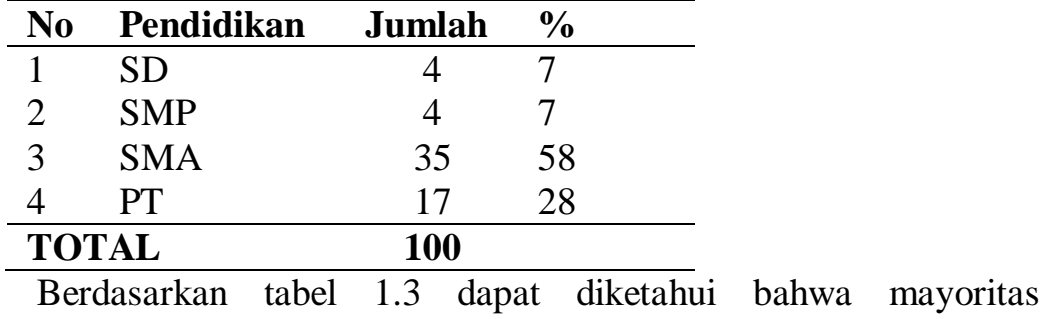

responden adalah ibu postpartum yang pendidikan terakhirnya adalah SMA yaitu sebesar 35 responden (58\%)

\section{Pengaruh Penggunaan ASI pada Luka Perinieum dengan Lama Penyembuhan Luka}

Tabel 1.4 Pengujian Hipotesis

\begin{tabular}{lrcc}
\hline Lama & waktu & $\mathrm{f}$ & sig \\
\cline { 3 - 4 } $\begin{array}{l}\text { kesembuhan } \\
\text { perineum }\end{array}$ & luka & 108,195 & 0,000 \\
kelompok & antar & & \\
\hline
\end{tabular}

Berdasarkan hasil analisis Uji anova diperoleh harga $\mathrm{F}$ hitung 108,195 dengan signifikansi sebesar 0,00<0,05, maka Ho ditolak dan Ha diterima artinya terdapat pengaruh yang signifikan antara penggunaan ASI dengan lama waktu penyembuhan luka perineum.

\section{B. PEMBAHASAN}

Berdasarkan uji anova yang telah dilakukan pada penelitian ini diketahui bahwa terdapat pengaruh yang signifikan antara penggunaan asi dengan lama waktu penyembuhan luka perinium. Hal ini sejalan dengan penelitian terdahulu yang dilakukan oleh Fita Supriyanik tahun 2011 bahwa perawatan tali pusat akan lebih cepat mengering jika menggunakan asi sebagai antiseptik karena asi mengandung anti infeksi dan anti inflamasi sehingga menyebabkan waktu pelepasan tali pusat lebih singkat. Diketahui perawatan menggunakan asi memiliki banyak manfaat dan lebih mudah dilakukan oleh ibu.

Setelah mempelajari unsur-unsur yang terdapat dalam ASI pemberian para donor, ilmuwan dari Brigham \& Women's Hospital menemukan bahwa ASI 
Jurnal Kebidanan Mutiara Mahakam, Vol 7 , No 2, 2019, Hal 67-73

juga mengandung molekul yang disebut specialized pro-resolving mediators (SPMs) yang mampu menyembuhkan luka, seperti peradangan dan infeksi.

ASI juga mengandung faktor proteksi yang bukan termasuk sistem imunologik seperti lisozim, laktoferin, oligosakarida, asam lemak yang semuanya berperan selain sebagai faktor protektif juga mengandung beberapa faktor untuk pertumbuhan serta pematangan sistem imun dan metabolik. ASI juga mengandung berbagai komponen anti-inflamasi seperti vitamin A, C, dan E, sitokin, enzim dan inhibitor enzim, prostaglandin E dan faktor pertumbuhan.

\section{SIMPULAN}

Berdasarkan dari hasil uji hipotesis (Anova) diperoleh $\mathrm{F}$ hitung 108,195 dengan signifikansi sebesar $0,00<0,05$. Dari hasil tersebut diartikan ada terdapat pengaruh yang signifikan antara penggunaan ASI dengan lama waktu penyembuhan luka perineum.

\section{DAFTAR PUSTAKA}

Admasari Yuli, Breast Milk As An Alternative For Postpartum Perineal Care. Belitung Nursing Jurnal.2017; 3(3):238-245

Allam NA, Wafa A, Talat AM. The Effect of Topical Application of Mother Milk on Separation of Umbilical Cord for Newborn Babies. American Journal of Nursing. 2015;4(5):288-296.

Arnardottir H, Orr SK, Dalli J, Serhan CN. Human milk proresolving mediators stimulate resolution of acute inflammation. Mucosal immunology. 2016;9(3):757-766.

Davidson N. REEDA: evaluating postpartum healing. Journal of nurse-midwifery. 1974;19(2):6-8

Depkes RI. Manajemen laktasi. Buku Panduan bagi Bidan dan Petugas Kesehatan di Puskesmas. 2005 6. Dinkes. Health Profile of East Java: Department of Health of East Java, Indonesia; 2014

Ginjala V, Pakkanen R. Determination of transforming growth factor-beta 1 (TGF-beta 1) and insulin-like growth factor (IGF-1) in bovine colostrum samples. Journal of immunoassay. May-Aug 1998;19(2-3):195-207

Gope R. The effect of epidermal growth factor \& platelet-derived growth factors on wound healing process. Indian Journal of Medical Research. 2002;116:201.

Kurniarum A, Kurniawati A. Keefektifan Penyembuhan Luka Perineum Pada Ibu Nifas Menggunakan Daun Sirih. Jurnal Terpadu Ilmu Kesehatan. 2015;4(2) 
Jurnal Kebidanan Mutiara Mahakam, Vol 7 , No 2, 2019, Hal 67-73

Muhith A. Hubungan antara Perawatan Luka Jahitan Perineum dengan Proses Kesembuhan Luka Perineum di RSUD Sidoarjo. Medica majapahit. 2009;1(1).

Price SA, Wilson LM. Patofisiologi konsep klinis prosesproses penyakit. Jakarta: EGC. 2005;7 12. Priddis H, Schmied V, Dahlen H. Women's experiences following severe perineal trauma: a qualitative study. BMC women's health. 2014;14(1):32

Sofiana E, Agustina Eko E, Efektifitas Metode Kolostrum Dan Metode Kasa Kering Terhadap Waktu Pelepasan Tali Pusat Di Bps Ny. Endang Purwaningsih Dan Bps Ny. Istiqomah Kecamatan Rakit Kabupaten Banjarnegara Tahun 2011. Bidan Prada : Jurnal Ilmiah Kebidanan, Vol.3 No.2 Edisi Desember 2011

Vural G, Kisa Sezer. Umbilical Cord Care: A Pilot Study Comparing Topical Human Milk, Povidone- Iodine anda Dry Care. JGONN Clinical Research. Jan-Feb 2006 